\title{
Thrombin and plasmin activity in coronary artery disease
}

\author{
M SMALL, G D O LOWE, J T DOUGLAS, I HUTTON, * A R LORIMER, * \\ C D FORBES \\ From the University Departments of Medicine and Cardiology, Royal Infirmary, Glasgow
}

SUMMARY Basal plasmin and thrombin activity in plasma were assessed by radioimmunoassay of the fibrinogen derivatives containing the sequence $B \beta_{15-42}$ and of fibrinopeptide $A$ respectively in a cross sectional controlled study of men with coronary artery disease. Compared with healthy controls $(n=33)$ men with angiographically defined coronary artery disease $(n=98)$ had a modest but significant increase in concentrations of fibrinopeptide $A$, indicating an activated coagulation system. Concentrations of $\mathrm{B} \beta_{15-42}$ were similar in those with coronary artery disease and in the controls.

The enhanced thrombin activity in coronary artery disease is in keeping with current evidence suggesting an association between coronary artery disease and a hypercoagulable state.

Recent interest in the role of haemostasis in vascular disease was prompted by studies showing an association between haemostatic variables and ischaemic heart disease $\mathrm{e}^{1-3}$ and by prospective studies which show that increased fibrinogen, in particular, is associated with ischaemic heart disease. ${ }^{4-6}$ Sensitive radioimmunoassays have become available for measurement of the fibrinogen derivatives, fibrinopeptide $A$ (an indicator of thrombin degradation of fibrinogen in vivo) and $B \beta_{15-42}$-containing peptides (an indicator of plasmin mediated fibrin(ogen)olysis). Simultaneous measurement of these peptides permits the balance between fibrinolysis and coagulation to be estimated. Since it has been postulated that the patency of the vascular system depends on the dynamic equilibrium between fibrinolysis and coagulation, ${ }^{7}$ these peptides could provide a measure of the risk of thrombosis. ${ }^{8}$ Compared with control subjects, fibrinopeptide A concentrations have been reported to be raised ${ }^{9}$ or normal $^{10}$ in subjects with ischaemic heart disease. The concentrations of $B \beta_{15-42}$ peptides in patients with coronary artery disease have not been studied and therefore we have measured these fibrinogen derivatives in a controlled study to establish whether coronary artery disease is associated with an imbalance between fibrinolysis and coagulation.

Requests for reprints to Dr M Small, Gartnavel General Hospital, 1053 Great Western Road, Glasgow G12 0YN.

Accepted for publication 18 May 1988

\section{Patients and methods}

Informed consent was obtained from 98 white men who had been admitted for elective coronary angiography for investigation of ischaemic cardiac pain. Because acute arterial vascular events have been shown to alter some tests of haemostasis ${ }^{112}$ we excluded patients who had sustained a myocardial infarction within three months of coronary investigation. We studied a control group of 33 white, healthy factory employees. These men lived in the same area as the patients with coronary disease. The control subjects were not receiving any drug treatment, were not hypertensive (blood pressure $<160 / 95 \mathrm{~mm} \mathrm{Hg}$ ), and gave no family history of ischaemic heart disease or diabetes mellitus. Random urinalysis and the measurement of concentrations of plasma glucose in fasting subjects excluded undiagnosed asymptomatic diabetes mellitus. The body mass index (weight $(\mathrm{kg})$ / height $\left(\mathrm{m}^{2}\right)$ ) was calculated as a measure of overweight or underweight. ${ }^{13}$

\section{METHODS}

A single resting blood sample was taken with minimal venostatis from fasted subjects between 7 and 9 am. Citrated blood was taken for radioimmunoassay of plasma $B \beta_{15-42}$ peptides and fibrinopeptide $A$ (IMCO, Stockholm) as previously described. ${ }^{14} 15$ Coronary angiography was performed by the Judkins' technique ${ }^{16}$ and blood samples were taken before this procedure. Coronary artery disease was 
scored as the number of major vessels with a reduction of the luminal diameter of $\geqslant 50 \%$.

\section{STATISTICAL ANALYSIS}

The distribution of fibrinopeptide $A$ and $B \beta_{15-42}$ peptides was skewed. Log transformation provided the best approximation to a normal distribution. The principal aim of the study was to assess whether the peptide concentrations were different in coronary heart disease and this was analysed by the unpaired Students $t$ test on $\log$ transformed data. A one factor analysis of variance (ANOVA) was used to assess the effect of the severity of coronary artery disease on the peptide concentrations.

\section{Results}

The two groups were well matched for age, body mass index, and smoking (table). The table lists the $\log$ transformed values for $B \beta_{15-42}$ and fibrinopeptide A. Concentrations of $\mathrm{B} \beta_{15-42}$ were similar in the controls and in the patients with coronary artery disease. Fibrinopeptide A concentration were higher in patients with coronary artery disease $(p<0.05)$ than in controls. When the log data on the four groups (controls and patients with one, two, or three vessel disease) were evaluated by one factor ANOVA, the differences were not statistically significant ( $F$ value $2 \cdot 249, p=0.08$ ), although in patients with two and three vessel disease mean fibrinopeptide A concentrations were $48 \%$ and $39 \%$ higher than in the controls (figure). Peptide concentrations in patients with a previous myocardial infarction $(n=55)$ were similar to those in patients with coronary artery disease but no previous thrombotic event $(n=43)$, and antianginal treatment $(\beta$ adrenoceptor blockade, calcium channel antagonists, nitrates) did not influence either $\mathrm{B} \beta_{15-42}$ or fibrinopeptide A concentrations.

Table Clinical and haemostatic variables (mean (SD)) in men with coronary artery disease (CAD) and controls

\begin{tabular}{|c|c|c|}
\hline & Controls & $C A D$ \\
\hline $\begin{array}{l}\text { Number } \\
\text { Age (years) } \\
\text { Body mass index } \\
\text { Smokers } \\
\text { (\%) } \\
\text { Fibrinopeptide A } \\
\text { (pmol/ml) } \\
\text { B } \beta_{15-42} \\
(\mathrm{pmol} / \mathrm{ml})\end{array}$ & $\begin{array}{l}33 \\
46 \cdot 5(6 \cdot 1) \\
25 \cdot 7(2 \cdot 4) \\
11 \\
(33) \\
1.61 \\
(1.31-1 \cdot 96) \\
2.06 \\
(1 \cdot 12-3 \cdot 34)\end{array}$ & $\begin{array}{l}98 \\
49 \cdot 6(8 \cdot 3) \\
26 \cdot 1(2 \cdot 3) \\
42 \\
(43) \\
2 \cdot 09 \star \\
(1 \cdot 84-2 \cdot 37) \\
1.63 \\
(1 \cdot 36-1 \cdot 94)\end{array}$ \\
\hline
\end{tabular}

Fibrinopeptide $A$ and $B \beta_{15-12}$ are given as mean and $95 \%$ confidence intervals.

${ }^{\star} \mathrm{p}<0.05$ compared with controls.

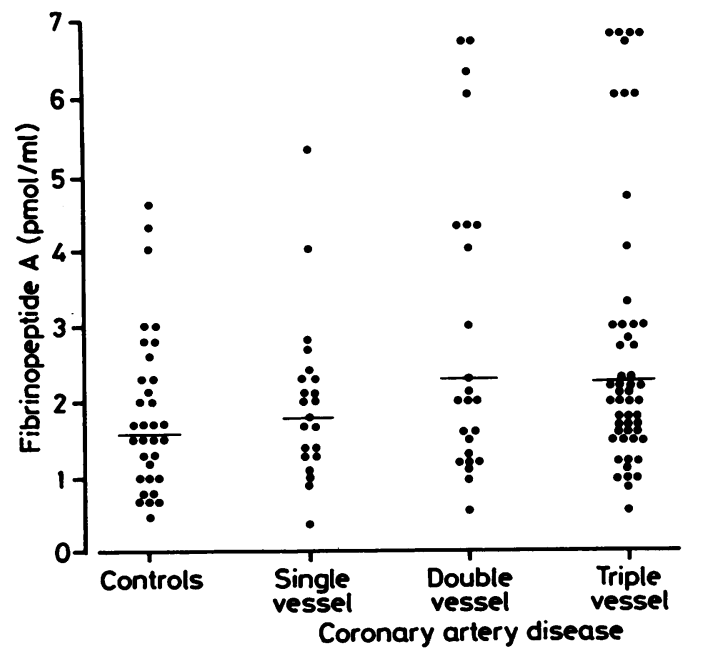

Figure Concentrations of fibrinopeptide $A$ in controls and in patients with coronary artery disease subdivided according to the extent of coronary artery disease. The horizontal bar indicates the geometric mean value.

\section{Discussion}

We found a modest but significant increase in fibrinopeptide $\mathbf{A}$ in patients with coronary artery disease, indicating an increase in thrombin degradation of fibrinogen in such patients. This result accords with a previous study. ${ }^{9}$ Although there were no statistically significant differences in fibrinopeptide $\mathrm{A}$ concentrations between patients with coronary artery disease of varying severity, the higher concentrations in patients with double and $\vec{D}$ triple vessel disease may be biologically important.

Earlier studies did not examine $\mathbf{B} \beta_{15-42}$ concentra- $\dot{\sigma}$ tions in coronary artery disease and we did not find 3 any differences in unstimulated, resting $\mathbf{B} \beta_{15-42}$ con- $\delta$ centrations between patients and healthy controls. This finding could be interpreted in two different $O$ ways. The obvious suggestion is that plasmin- $D$ mediated fibrin(ogen)olysis is not altered by the presence of coronary artery disease. Alternatively, an activated coagulation system (as shown by raised ${ }^{\circ}$ fibrinopeptide A concentrations) could lead to a $\mathbb{N}$ secondary activation of fibrinolysis, and the absence $\underset{\omega}{\mathcal{E}}$ of an increase in $B \beta_{15-42}$ concentrations may reflect an abnormal response of the fibrinolytic enzyme system. 0 Dynamic tests of plasma fibrinolytic potential $\overparen{D}$ showed that abnormalities of fibrinolysis are more ? common in men with ischaemic heart disease $e^{317} 18$ and 7 more recent studies have shown that this finding may

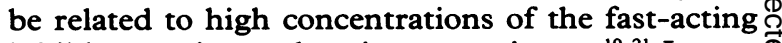
inhibitor to tissue plasminogen activator ${ }^{19-21}$ It may $\mathbb{\Omega}$ 
be that dynamic stimuli such as exercise or venous occlusion might unmask defective plasmin activity (as measured by changes in $\mathrm{B} \beta_{15-42}$ concentrations) in coronary artery disease but this suggestion requires further study. None the less, the results of our study accord with growing evidence that ischaemic heart disease is associated with haemostatic disturbance. ${ }^{1-3}$

We thank Dr G Gettinby for statistical advice.

\section{References}

1 Meade TW, North WRS, Chakrabarti R, et al. Haemostatic function and cardiovascular death: early results of a prospective study. Lancet 1980;i:1050-4.

2 Baker IA, Eastham R, Elwood PC, Etherington $M$, O'Brien JR, Sweetnam PM. Haemostatic factors associated with ischaemic heart disease in men aged 45-64 years. The Speedwell study. Br Heart J 1982;47:490-4.

3 Yarnell JWG, Sweetnam PM, Elwood PC, et al. Haemostatic factors and ischaemic heart disease. The Caerphilly study. Br Heart $J$ 1985;53:483-7.

4 Wilhelmsen L, Svardsudd K, Korsan-Bengtsen K, Larsson B, Welin L, Tibblin G. Fibrinogen as a risk factor for stroke and myocardial infarction. $N$ Engl $J$ Med 1984;311:501-5.

5 Stone MC, Thorpe JM. Plasma fibrinogen-a major coronary risk factor. $J R$ Coll Gen Pract 1985;35: 565-9.

6 Meade TW, Mellows S, Brozovic M, et al. Haemostatic function and ischaemic heart disease: principal results of the Northwick Park Heart Study. Lancet 1986;ii:533-7.

7 Astrup T. The haemostatic balance. Thromb et Diath Haemorrh 1958;2:347-57.

8 Nossel HL. Relative proteolysis of the fibrinogen $B \beta$ chain by thrombin and plasmin as a determinant of thrombosis. Nature 1981;291:165-7.

9 Neri Serneri GG, Gensini GF, Abbate R, et al. Increased fibrinopeptide $A$ formation and thromboxane $A_{2}$ production in patients with ischaemic heart disease: relationships to coronary pathoanatomy, risk factors, and clinical manifestations. Am Heart J 1981;101:185-94.

10 Nichols AB, Owen J, Kaplan KL, Sciacca RR, Cannon PJ, Nossel HL. Fibrinopeptide A, platelet factor 4 and $\beta$-thromboglobulin levels in coronary heart disease. Blood 1982;60:650-4.

11 Haines AP, Howarth D, North WRS, et al. Haemostatic variables and the outcome of myocardial infarction. Thromb Haemost 1983:50:800-3.

12 Lane DA, Wolff S, Ireland H, Gawel M, Foadi $M$. Activation of coagulation and fibrinolytic systems following stroke. $\mathrm{Br} J$ Haematol 1983;53:655-8.

13 Truswell AS. Obesity; diagnosis and risks. $\mathrm{Br} \mathrm{Med} J$ 1985;291:655-7.

14 Douglas JT, Lowe GDO, Forbes CD, Prentice CRM. Plasma fibrinopeptide $A$ and beta-thromboglobulin in patients with chest pain. Thromb Haemost 1983;50:541-2.

15 Douglas JT, Blamey SL, Lowe GDO, Carter DC, Forbes CD. Plasma beta-thromboglobulin, fibrinopeptide $A$ and $B \beta_{15-12}$ antigen in relation to postoperative DVT, malignancy and stanozolol treatment. Thromb Haemost 1985;53:235-8.

16 Judkins HP. Selective coronary angiography, A transcutaneous approach. Radiology 1967;89:815-24.

17 Walker ID, Davidson JF, Hutton I, Lawrie TDV. Disordered "fibrinolytic potential" in coronary artery disease. Thromb Res 1977;10:509-20.

18 Khanna PK, Seth HN, Balasubramanian V, Hoon RS. Effect of submaximal exercise on fibrinolytic activity in ischaemic heart disease. Br Heart $J$ 1975;37: $1273-6$.

19 Paramo JA, Colucci M, Collen D, van de Werf F. Plasminogen activator inhibitor in the blood of patients with coronary artery disease. $\mathrm{Br} \mathrm{Med} \mathrm{J}$ 1984;291:573-4.

20 Hamsten A, Wiman B, de Faire U, Blombäck $M$. Increased plasma levels of a rapid inhibitor of tissue plasminogen activator in young survivors of myocardial infarction. N Engl J Med 1985;313:1557-63.

21 Hamsten A, Blombäck M, Wiman B, et al. Haemostatic function in myocardial infarction. Br Heart $J$ 1986;55:58-66. 